\title{
PROCESO DE MUTACIÓN CULTURAL DESDE EXPERIENCIAS COTIDIANAS EN VILLA PUCLARO
}

Giancarla Gómez Passalacqua ${ }^{1}$

\section{Resumen}

Las erradicaciones masivas traen consecuencias socioculturalesy transformaciones en el territorio que determinan el contexto de los procesos de Mutación Cultural, generando el deterioro del tejido social y urbano del Hábitat Residencial de poblaciones en condición socioeconómica vulnerable.

La relación sistémica entre efectos socioculturales, nuevas experiencias cotidianas y prácticas culturales en estado de transición, configuran el andamiaje que produce la transformación del universo simbólico de los habitantes, su pérdida de identidad, de pertenencia y de interacción social.

Desde este escenario complejo, la creación espontánea de una habitante erradicada -una poesíainspirada en el desaparecido poblado Punta Azul, permitió vislumbrar problemáticas de exclusión social y segregación urbana, como signos alienantes del desarrollo económico y la globalización.

Arquitecto Universidad de Chile. Magíster (〔) en Hábitat Residencial. Facultad de Arquitectura y Urbanismo. Universidad de Chile. Correo electrónico: gmgpassalacqua@gmail.com

Este documento esta basado enla monografía final, Módulo Evaluación Socioeconómica del Hábitat, Magister en Hábitat Residencial.
La dificultad de adaptación y apropiación de nuevas experiencias cotidianas, condiciona la reconstrucción social de identidad y arraigo, frena la disminución de los efectos socioculturales y potencia el deterioro y la insustentabilidad social y urbana del poblado.

Investigar la transformación del universo simbólico de habitantes erradicados -desde Poesías Iconográficas-, es comprender las causas del deterioro social, develando el "eslabón de enlace" de un proceso cultural que recoge los vestigios ontológicos del pasado, y los integra al presente cotidiano en su nuevo vínculo territorial.

CONCEPTOS CLAVES: UNIVERSO SIMBÓLICO, PROCESO DE MUTACIÓN CULTURAL, EXPERIENCIAS COTIDIANAS, CONSTRUCCIÓN DE IDENTIDAD Y ARRAIGO, POESÍAS ICONOGRÁFICAS. 


\section{Introducción}

\section{ERRADICACIÓN DEL POBLADO PUNTA AZUL Y LA POLVADA. NUEVA LOCALIZACIÓN EN VILLA PUCLARO.}

Los procesos de la economía global, el desarrollo de las tecnologías y las comunicaciones, traen consecuencias y transformaciones en la vida de las personas y también modificaciones en el territorio, a modo de huellas físicas en las ciudades, los paisajes urbanos y rurales, constituyéndose como expresión manifiesta de una sociedad marcada por las ventajas y desventajas del modelo económico imperante; la ciudad y el paisaje como vitrina de la opulencia y la marginalidad, consecuencia del éxito y el fracaso inherente al juego de intereses, protagonista de la toma de decisiones económicas y políticas.

Es así como la construcción del Embalse Puclaro (1996-1999) y la inundación de 830 hectáreas agrícolas en el Valle de Elqui, sumergió la historia y la identidad de los poblados de Gualliguaica, Punta Azul y La Polvada, y desencadenó un proceso de erradicación en favor de ganancias para el crecimiento económico de la Región de Coquimbo; pero sin embargo, significó la pérdida invalorable para 828 habitantes afectados por la Erradicación,

160 revista invi №66 / Agosto 2009 / Volumen № 24: 159-190 familias de pequeños agricultores y temporeros de la uva que obligadamente avanzaron hacia una pobreza más compleja ${ }^{2}$, aquella que integra carencias tradicionales e inmateriales, marcada por desigualdades profundas, enfatizada por la inseguridad y la incertidumbre de la flexibilidad laboral.

El desarrollo de las acciones generadas desde los poderes públicos, entiéndase Serviu, Intendencia, Seremis, Alcaldía y Dirección de Riego del Ministerio de Obras Públicas, en conjunto con la Asociación de Regantes del Valle de Elqui, impusieron las dinámicas de negociaciones con los propietarios de los terrenos y los habitantes afectados, bajo una evidente desigualdad entre ambos intereses y oportunidades. La consecuencia, finalmente, fue un proceso de erradicación que desencadenó paulatinamente un profundo deterioro del hábitat residencial y un desmoronamiento de sus valores endógenos, signo categórico de exclusión social y segregación espacial ${ }^{3}$, fundamentalmente por la localización aislada del nuevo poblado de Villa Puclaro y por

$\begin{array}{ll}2 & \text { Tironi, Manuel. 2001. Pp.27-38. } \\ 3 & \text { Barreiro, Fernando. 2002. }\end{array}$

ARTÍCULO: Proceso de mutación cultural desde experiencias cotidianas en Villa Puclaro / Giancarla Gómez Passalacqua 

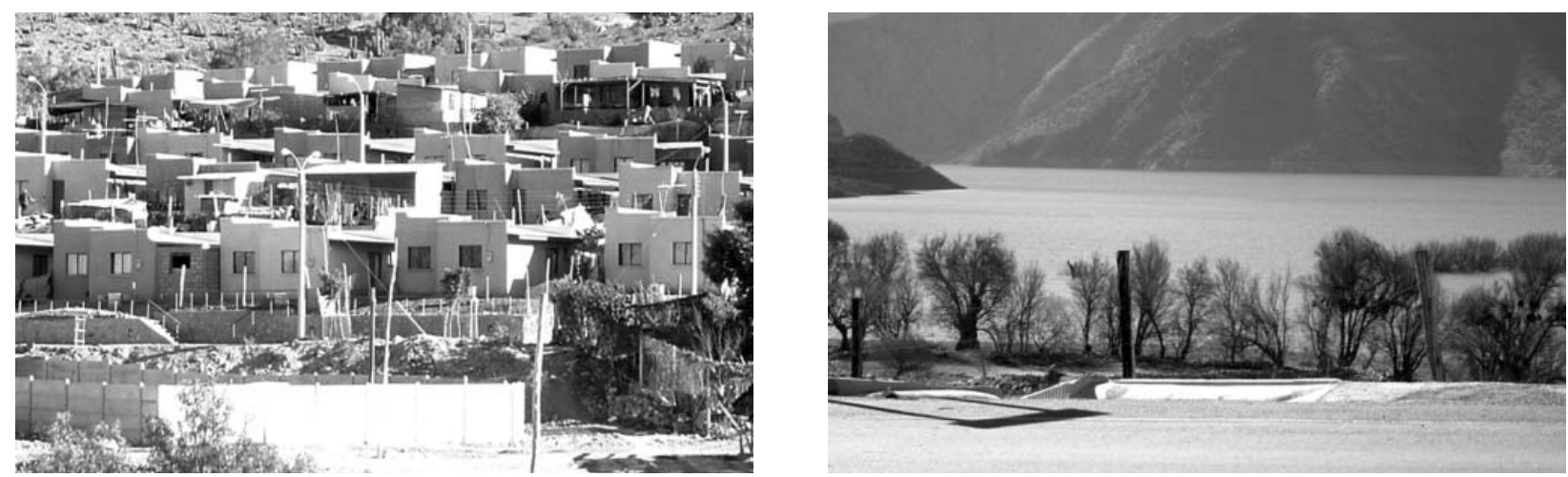

En medio de los cerros que conforman el Valle de Elqui, se observa Villa Puclaro con sus pequeñas viviendas que enfrentan el Embalse Puclaro. Fuente: Autora

la inexistencia de equipamiento comunitario e infraestructura complementaria, condiciones urbano arquitectónicas que no alcanzaron a disminuir en alguna medida los costes de oportunidad ${ }^{4}$, en este caso, los costos sociales generados por el poder del progreso y el crecimiento económico.

Desde lo anterior, el presente trabajo pretende situar la mirada en el Proceso de Mutación Cultural de Villa Puclaro y por ende, en las problemáticas que actualmente podrían estar siendo vivenciadas por sus habitantes, como una manera de proponer posibles herramientas factibles a ser utilizadas en la orientación de acciones conducentes a mitigar los efectos socioculturales producto de las erradicaciones.

4 Wonnacott, Paul y Wonnacott Ronald, pp. 3-27.
Es así, como las problemáticas y los fenómenos en torno a las transformaciones de la Cultura original y en este caso en particular, el debilitamiento de su cultura Rural, es un tema relevante de explorar en función del deterioro social de sus habitantes.

Los cuatro conceptos claves ancla, que estructuraron el hilo conductor de la monografía, son:

- Identidad Rural, como identidad cultural originaria.

- Transformación del Universo Simbólico.

- Proceso de Mutación Cultural como eslabón de enlace.

- Construcción de Nueva Identidad Cultural. 


\section{BOSQUEJO CONCEPTUAL 1: ESTRUCTURA CONCEPTUAL DE LA INVESTIGACIÓN.}

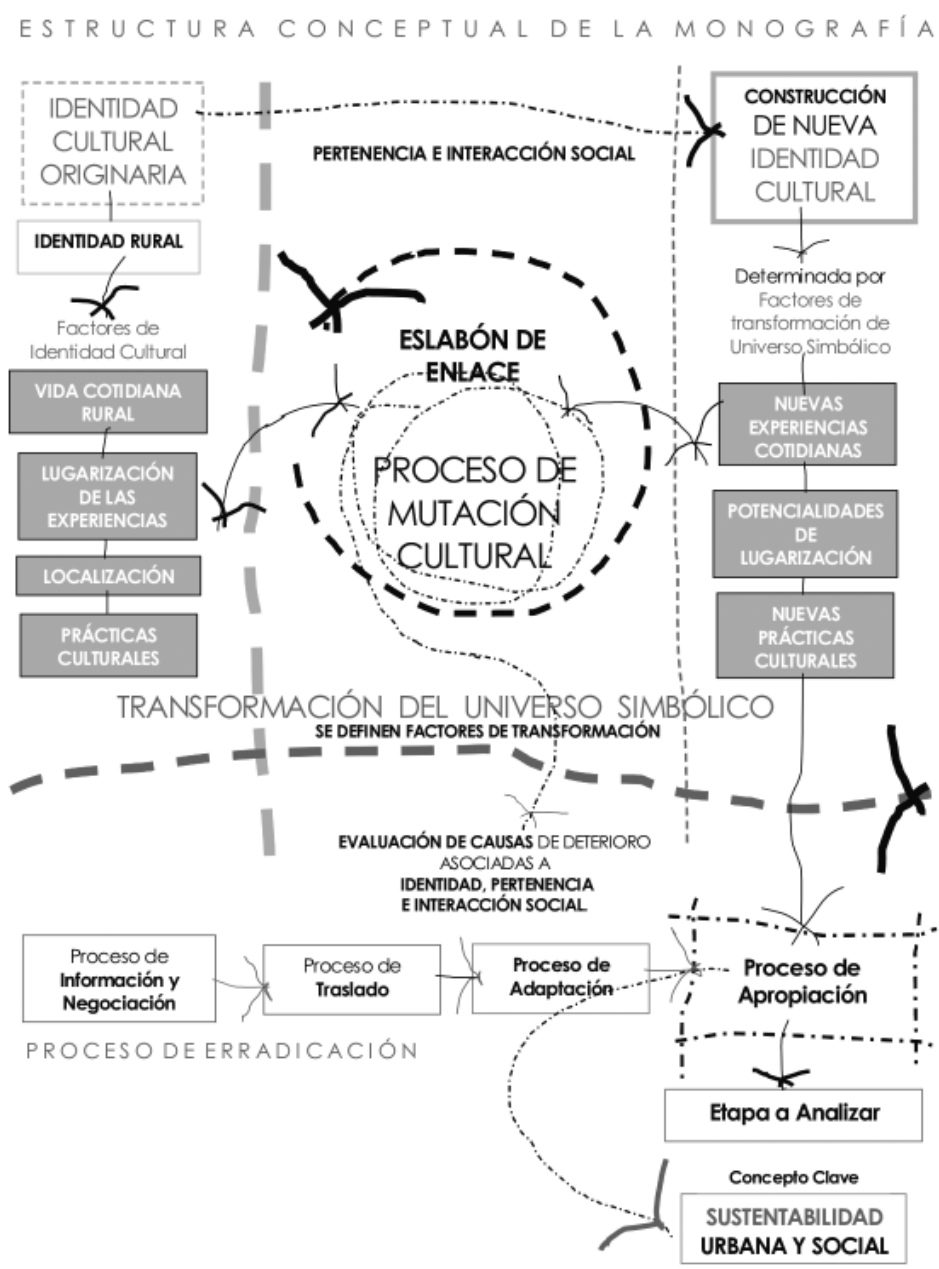

Fuente: Autora. 


\section{BOSQUEJO CONCEPTUAL 2: POESÍA DE PUNTA AZUL COMO EXPRESIÓN DE IMAGINARIOS SIMBÓLICOS.}

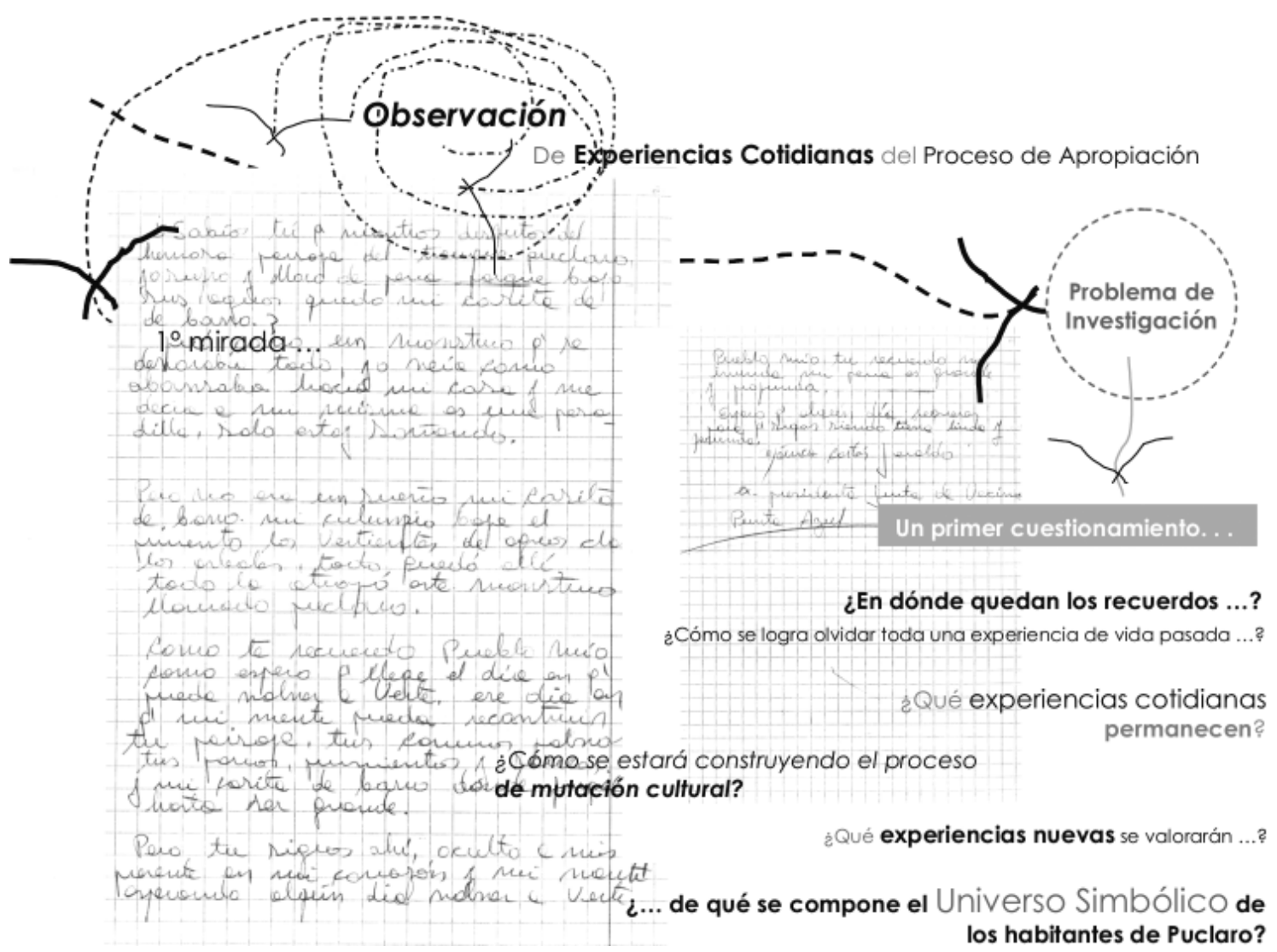

Fuente: Autora. 


\section{Intuición del problema y su contexto}

El "rompimiento de la invisibilidad cotidiana" que intuye los símbolos de una problemática compleja y silente, surge desde las expresiones voluntarias de comentarios opcionales registrados en encuestas aplicadas a la población en el otoño del 2008, y fundamentalmente a través de un regalo recibido de la Sra. Mónica Cáceres Jeraldo ${ }^{5}$; la creación de una poesía escrita por la dirigente comunal de la época de la erradicación.

Desde esta expresión artística "espontánea" ofrecida como un regalo invalorable, expresión de nostalgia y añoranzas, se develaron implícitamente los efectos socioculturales de la erradicación, asimismo, las nuevas experiencias cotidianas que han transformado radicalmente su universo simbólico.

En la totalidad de las encuestas realizadas, los habitantes expresaron añoranzas y nostalgia por su vida cotidiana pasada, recuerdos que permanecen en la memoria colectiva de las personas, y que son comunicadas bajo una mirada de insatisfacción sociocultural, efecto causado por la manera deshumanizada en que se desarrolló el

5 Presidenta de la Junta de Vecinos del desaparecido poblado de Punta Azul. Actor social en la época de la construcción del Embalse Puclaro y en el posterior proceso de Erradicación masiva hacia Villa Puclaro. proceso de erradicación y posteriormente por las nuevas condiciones urbanas y arquitectónicas de Villa Puclaro.

Los efectos socioculturales concluidos en la primera investigación monográfica de la serie de dos, como son la insatisfacción sociocultural, conflictos de convivencia, incremento del consumo de drogas y alcohol y percepción de estancamiento, nos sitúan en un soporte conceptual y simbólico que podría explicar, desde las nuevas experiencias cotidianas, el complejo escenario que está definiendo el proceso de Hibridación cultural ${ }^{6}$ y con ello, el multidimensional engranaje de las nuevas prácticas culturales y de la reconstrucción de identidad y arraigo, en una nueva localización territorial y en la fusión obligada de dos pueblos diferentes.

El problema, por ende, surge por las condiciones (efectos socioculturales) en que se está desarrollando el proceso de Adaptación y Apropiación de las nuevas experiencias cotidianas y las prácticas culturales modificadas por la erradicación.

La problemática observada desde las experiencias cotidianas del habitar y sus motivaciones profundas, se relaciona con lo que podríamos llamar un "Poblado en condición a la Deriva"...

6 García, Canclini. Cucó Giner, Josepa. 2004. Pp. 45-79. 
que al parecer carecería de una sinergia de herramientas sociales, culturales y económicas que les permitieran revertir su situación de deterioro, realidad que se ve enfatizada debido al abandono social y político en que se encuentran. Los pocos actores sociales que actualmente están generando acciones de movilización, son mujeres dirigentes vecinales que no encuentran el apoyo suficiente para llevar a cabo sus iniciativas de interacción social y desarrollo económico.

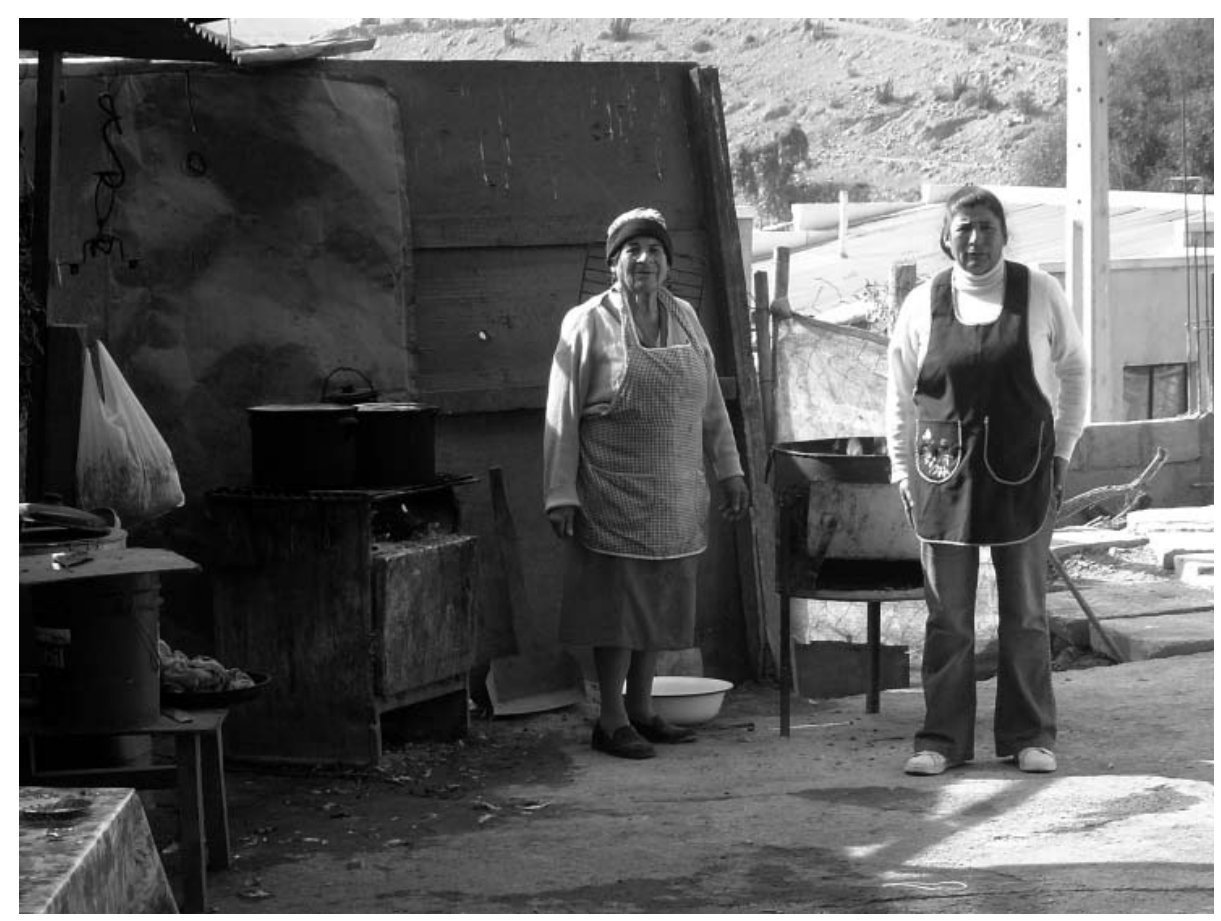

Dos habitantes de Puclaro, en sus cocinas a leñas al exterior de sus viviendas.

Signos de adaptación de prácticas culturales originarias, asociadas a la preparación de alimentos en hornos de barro.

Fuente: Autora. 
Una condicionante esencial del Proceso de Mutación Cultural de Puclaro está definida por la modificación radical del territorio, que inserta el proceso en los complejos paradigmas en torno a las transformaciones de la sociedad y la cultura contemporánea, que ponen en cuestionamiento la identidad en términos de dependencia con la interacción social, acotadaculturaly simbólicamente al espacio físico y al territorio.

Asimismo, las prácticas laborales temporarias, la inexistencia de fuentes laborales, de equipamientos y servicios, provocan una movilidad diaria, a modo de un habitar de experiencias cotidianas en flujo, deambulando en la dobley difusa coexistencia entre los espacios de lugares y de flujos, propio de las sociedades contemporáneas y del deterioro de la calidad de vida, generando la pérdida del vínculo identidad - territorio, dado por las tecnologías de comunicación y por el incremento de la sociedad de los flujos ${ }^{7}$, marcada además por la condición de movimiento, de cambio constante y de desarraigo ${ }^{8}$.

\section{Descripción desde el observador}

La declaración del problema está definida por una observación externa a la realidad de Puclaro, en la

7 Barreiro, Fernando. 2002.

8 García, Canclini. Cucó Giner, Josepa. 2004. Pp. 45-79. medida que se le asigna valor a la interpretación de las expresiones motivacionales declaradas en la poesía y en los comentarios voluntarios de la encuesta.

Es así, como se interpretan las problemáticas implícitas de los discursos, que describen y cualifican las nuevas experiencias cotidianas de los habitantes en su actual localización.

Asimismo, dejando de lado la interpretación del observador externo, la problemática también es declarada explícitamente por los habitantes involucrados en las encuestas parte "comentarios voluntarios", a través de declarar directamente sus necesidades y frustraciones experimentadas en la nueva vida cotidiana del poblado, donde aparece la valoración negativa explícitamente en la declaración manifiesta de disconformidad con las condiciones en que se está desarrollando su vida en Villa Puclaro, evidenciado en la solicitud de apoyo y ayuda social para su situación laboral y la solicitud de equipamiento y servicios del poblado, en casi la totalidad de los manuscritos.

La asignación negativa de la situación problema, desde la interpretación del observador externo, está fundamentada en la percepción de añoranzas y nostalgias que se advierten en la poesía y en muchos de los comentarios voluntarios, 
expresiones del universo simbólico que nos hablan de los efectos socioculturales de la erradicación y de necesidades no satisfechas... tanto de aquellas necesidades cotidianas como también de aquellas más profundas, arraigadas a su habitar interrumpido por la erradicación, es decir, en sus pensamientos que se aproximan al trasfondo de la vida, al apego a su morada, entendida como residencia y como paisaje, indudablemente huellas de la memoria significativa y ontológica del habitar.

\section{Planteamiento del problema}

Para todo proceso de erradicación masiva se han establecido como marco de análisis una estructura conceptual basada en cuatro etapas de desarrollo, Proceso de Información y Negociación, Proceso de Traslado, Proceso de Adaptación y Proceso de Apropiación, presentes genéricamente en todas las Erradicaciones masivas de población.

Lapresentemonografíaanalizaráfundamentalmentela $4^{a}$ Etapa definida como Apropiación, considerándola en su relación difusa con la $3^{\circ}$ Etapa anterior de Adaptación, centrándose en la observación de las experiencias cotidianas que definen la manera en que los habitantes de Villa Puclaro están construyendo sus prácticas culturales configuradoras de su nueva identidad y del arraigo.

ARTíCULO: Proceso de mutación cultural desde experiencias cotidianas en Villa Puclaro / Giancarla Gómez Passalacqua
A partir de situarnos en la Etapa de Apropiación, se incorporará como fuente de información del análisis el cuestionamiento planteado por Fernando Barreiro ${ }^{9}$, que desde las transformaciones de la cultura contemporánea pone en duda la relación existente entre identidad, pertenencia e interacción Social, centrando la mirada crítica en la Cultura y sus nuevos vínculos con el Territorio, que en este caso se hace pertinente por la problemática de un pueblo que ha perdido o cambiado sustancialmente la manera de relacionarse con su entorno natural y construido.

En la realización de la monografía inicial se comenzó a trazar el camino de investigación de la actual tesis en Villa Puclaro, comprendiendo los efectos socioculturales correspondientes a la última etapa llamada "Proceso de Apropiación", provocados por el hundimiento del poblado Punta Azul, La Polvada y Gualliguaica, en favor de la construcción del Embalse Puclaro.

Para dichos efectos socioculturales se establecieron las causas generadoras según las dimensiones Sociales, Territoriales, Políticas y Económicas que están involucradas en el Hábitat Residencial del proceso de erradicación; las cuales se constituyen como "el soporte inicial del problema a investigar".

El énfasis de la monografía como se explicará más adelante, estará dado en el planteamiento

9 Barreiro, Fernando. 2002. 
de posibles herramientas de análisis y monitoreo de las experiencias cotidianas en los procesos de Adaptación y Apropiación, que podrían ser utilizadas para mitigar los efectos socioculturales producto de erradicaciones.

\section{Causas observadas del problema}

Las causas de la problemática a investigar están relacionadas con una diversidad de factores que influyen sistémicamente entrelazando las tres dimensiones del hábitat residencial de Villa Puclaro.

Desde el primer trabajo monográfico, se han rescatado las causas generadoras de deterioro social y urbano, asimismo, se han establecido desde la mirada de la vida cotidiana, diferentes y nuevas causas observadas en relación a la dificultad de adaptación y apropiación de las experiencias cotidianas de los habitantes:

\section{DESDE LA DIMENSIÓN DEL HABITANTE Y SUS RELACIONES SOCIALES}

- Pobreza rural, carencia de herramientas socioculturales y económicas.

- Carencia de redes sociales de apoyo.
- Carencia de oportunidades.

- Carencia de Interacción social.

- Debilitamiento de acciones integradas de Junta de vecinos.

\section{DESDE LA DIMENSIÓN MEDIO AMBIENTE Y TERRITORIO}

- Localización aislada

- Inexistencia de Equipamientos y Servicios.

- Características de la movilidad cotidiana.

- Carencia de Diseño Urbano.

- Carencia de suelo disponible.

\section{DESDE LA DIMENSIÓN SOCIAL, POLÍTICA Y ECONÓMICA}

- Carencia de Planes y Programas de apoyo social.

- Desarticulación de iniciativas locales y externas.

- Desaprovechamiento de focos de atracción potencialmente explotables (turismo).

- Inexistencia de focos laborales internos al poblado.

- Carencia de condiciones que faciliten una Economía de Escala. ${ }^{10}$

10 Camagni, Roberto, 2005. Pp. $21-50$. 


\section{Énfasis de la monografía}

El presente trabajo pretende basarse en las causas que estarían provocando los efectos socioculturales manifestados en la Etapa de Apropiación y vinculadas con la dimensión del habitante y sus relaciones sociales, con el objetivo de ser analizadas a la luz de posibles herramientas de evaluación y monitoreo factibles de ser aplicadas en los proceso de Mutación Cultural producto de erradicaciones, orientando la formulación de posibles propuestas de recuperación de tejido social y urbano.

Desde el planteamiento del problema y la complejidad del término Cultura y desde los factores presentes en las transformaciones de la sociedad, surge la necesidad de incorporar concientemente al análisis del Proceso de Mutación Cultural, los componentes que articulan sus nuevos paradigmas. Es así como se establecen tres ejes conceptuales de análisis, como soporte permanente de la reflexión, éstos son: La Identidad, La Pertenencia y La Interacción Social, como ejes generadores de posibles líneas de acción, centrados en el objetivo de "intervenir las causas" y/o "mitigar los efectos adversos" y el deterioro social producto de las erradicaciones, develando desde el Proceso de Mutación Cultural el Universo Simbólico de sus habitantes.

\section{Ejes conceptuales y causas generadoras de efectos socioculturales}

\section{IDENTIDAD}

Causa de Deterioro Asociada: Carencia de experiencias cotidianas vinculadas a la identidad original, en sus formas, usos y significación.

\section{PERTENENCIA}

Causa de Deterioro Asociada: Carencias de vinculación y adscripción de los habitantes a un grupo social unitario y a condiciones urbano arquitectónicas deficientes.

\section{INTERACCIÓN SOCIAL}

Causa de Deterioro Asociada: Debilitamiento de relaciones y mutuas influencias de carácter cultural, que promuevan los vínculos sociales primarios y secundarios.

\section{Definición de la problemática y pregunta a responder}

El planteamiento del problema se define como la "dificultad de adaptación y apropiación de nuevas experiencias cotidianas, que estarían retardando 
la reconstrucción de identidad y de arraigo, asimismo, frenando la disminución de los efectos socioculturales de la erradicación, potenciando el deterioro y la insustentabilidad social y urbana del poblado".

Desde dicho problema nos cuestionamos... ¿De qué manera las Poesías Iconográficas podrían aplicarse como herramientas de evaluación de las experiencias cotidianas que permanecen en la memoria colectiva de los habitantes; y de aquellas prácticas culturales que han logrado mantenerse y/o modificarse en los Procesos de Adaptación y Apropiación producto de Erradicaciones?

\section{Objetivo general de investigación}

Generar herramientas de evaluación y monitoreo de los procesos de Adaptación y Apropiación de poblaciones erradicadas, basados en la observación de experiencias cotidianas como vitrina de análisis, que permitan facilitar y orientar el acompañamiento $y$ apoyo a comunidades afectadas, asimismo, tendientes a potenciar la construcción de una nueva identidad y arraigo, disminuyendo los efectos socioculturales producto de la erradicación y frenando la progresión del deterioro social y urbano.

170 revista invi № 66 / Agosto 2009 / Volumen № 24: 159-190

\section{Objetivos específicos}

- Crear instrumentos de evaluación y monitoreo de experiencias cotidianas de los habitantes, basados en la observación y el análisis interpretativo de imágenes poéticas, como expresión del universo simbólico, de motivaciones, necesidades y sueños, permitiendo fortalecer la construcción de identidad y arraigo.

- Contribuir a partir de Poesías Iconográficas a los procesos de Adaptación y Apropiación de nuevas experiencias cotidianas, que permitan disminuir los efectos socioculturales generados en los procesos de mutación cultural producto de erradicaciones.

\section{Antecedentes conceptuales}

\section{FUNDAMENTACIÓN TEÓRICA Y CONCEPTOS CLAVES ANCLA}

La estructura conceptual de la monografía está basada en cuatro conceptos claves ancla, que se ubican en línea de tiempo en el proceso de erradicación:

La Identidad cultural (rural) de los pueblos de Punta Azul y La Polvada se definen como 


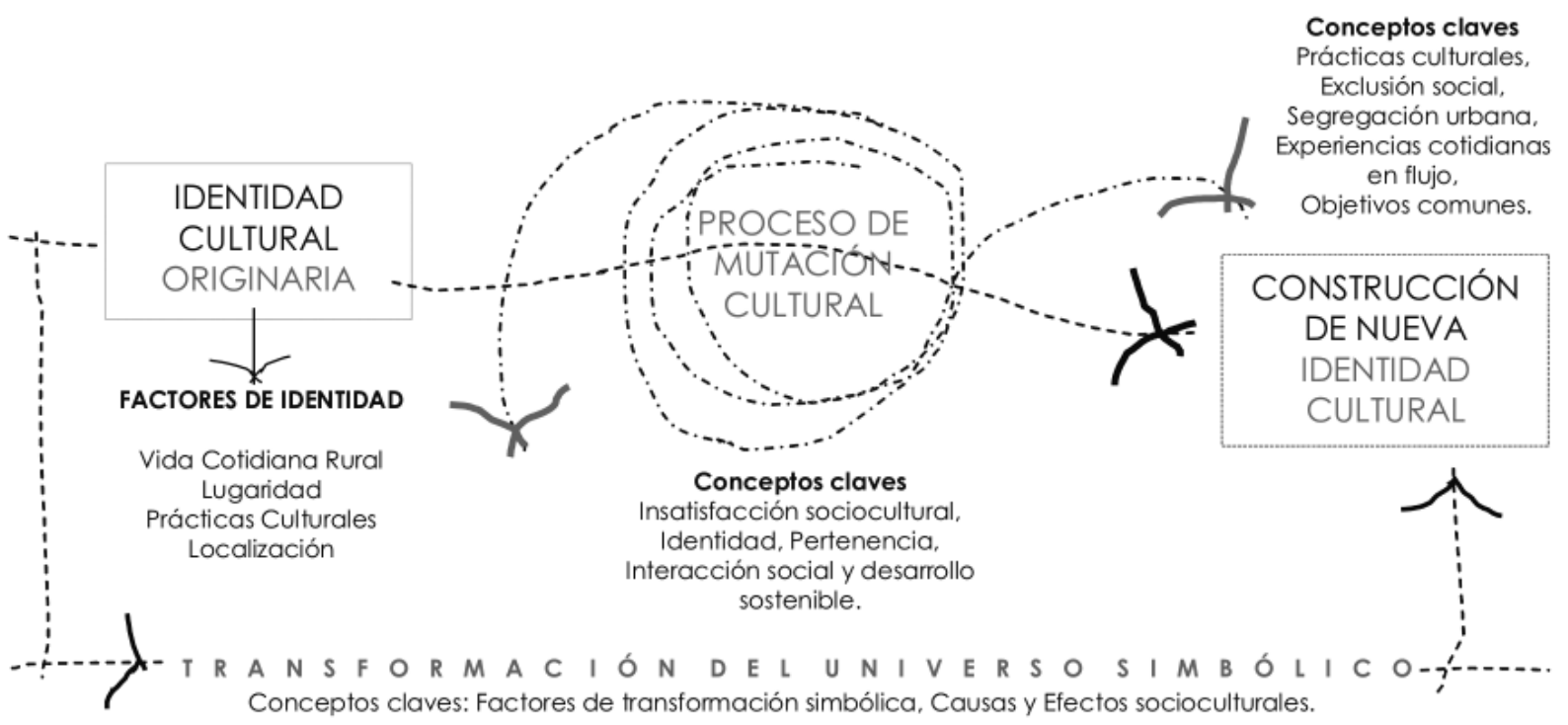

Fuente: Autora

ancla conceptual de origen, luego el proceso de Mutación cultural como eslabón que enlaza la transformación sociocultural de la población erradicada, y posteriormente la consolidación paulatina de la nueva identidad cultural. El concepto que engloba a los tres anteriores es la transformación del Universo Simbólico como el motor generador de la construcción de nueva identidad.

\section{Identidad cultural originaria}

Los factores que se definen como generadores de Identidad cultural originaria son los siguientes:

\section{VIDA COTIDIANA RURAL}

Anterior a la erradicación, la identidad cultural en los poblados de Punta Azul y La Polvada estaba marcada fundamentalmente por sus condiciones particulares 
de ruralidad, dadas por la subsistencia a través del cultivo y recolección de la producción de viñedos, actividad laboral característica del Valle de Elqui.

Las dos características básicas que determinan al mundo rural son, en primer lugar, la identificación con la actividad agraria y, en segundo lugar, la identificación con el "vivir" en un núcleo rural, destacándose como positivo las relaciones sociales propias de un pueblo, la valoración de la calidad de vida entendido como tranquilidad y naturaleza, los lazos familiares y vecinales como reconocimiento de una historia en común, que conlleva relaciones infancia, la relación comunitaria de actividades, trabajos y celebraciones conjuntas.

Se puede afirmar desde lo anterior, que la identidad cultural se conforma en el día a día, a través de la simpleza de las experiencias cotidianas, de situaciones diarias que le otorgan a la vida sentido y protección. La identidad y la cultura están, por ende, relacionadas inherentemente a la pertenencia, condición generada por el pasar de los días y sus actividades simples y muchas veces rutinarias, y también desde la interacción social, es decir, desde las experiencias cotidianas compartidas, fortalecidas por redes y vínculos intensas de mutua ayuda, de protección hacia la

generados con los otros, con proyectos comunes que los reflejen y motiven.

\section{LUGARIZACIÓN DE LAS EXPERIENCIAS}

Los poblados de Punta Azul y La Polvada, a pesar de estar físicamente bajo las aguas del embalse, se constituyen para los habitantes de Villa Puclaro en la referencia más profunda de arraigo a un lugar, que representa emocionalmente su historia y su origen, como individuos y como comunidad.

Desde esta concepción de dependencia entre lugar y habitante, se vuelven esenciales los vínculos socioculturales que permanecen en la memoria colectiva de las personas, puesto que se transforman en soportes de la identidad de los pueblos erradicados.

Surge desde lo anterior, el fundamento de la "relevanciadellugar" paraloshabitanteserradicados, y con ello la asociación al caso de estudio, de las dos tendencias que marcan, según González Cruz ${ }^{11}$, la finalización del siglo XX y el inicio del siglo XXI; la globalización y la lugarización.

La globalización está expresada claramente en la construcción delEmbalse Puclaro, afavor del progreso

11 González Cruz, Francisco, Geógrafo y Magíster en Planificación Urbana y Regional. Promotor de diversos proyectos de desarrollo regional y local, principalmente en el Estado de Trujillo. Profesor de pre y postgrado en diversas universidades venezolanas y Rector de la Universidad Valle del Momboy, Venezuela 2004.

172 revista invi №66 / Agosto 2009 / Volumen № 24: 159-190 
económico y el desarrollo regional. Asimismo, se asocia a los procesos de lugarización, la pérdida de las experiencias de vida interrumpidas por la erradicación, como parte constituyente de las causas y posteriores efectos socioculturales sufridos por la población, fundamentalmente por la valorización de sus propias raíces culturales y sociales.

La importancia de los fenómenos relacionados con la lugarización de las experiencias en Punta Azul y La Polvada se vuelven relevantes para el estudio del Proceso de Mutación Cultural, puesto que validan aquellas experiencias que permanecen arraigadas en la memoria colectiva de los habitantes de Puclaro y que, de alguna manera, ensombrecen por el recuerdo y la añoranza, la construcción de las nuevas prácticas culturales generadoras de identidad, pertenencia e interacción social.

Los procesos de lugarización, que transitan en forma paralela a la globalización económica, tecnológica y de comunicaciones, otorgan la revalorización de lo local en lo global, centrando sus valores en las cualidades de la propia identidad del lugar y en las relaciones socioculturales de sus habitantes, expresando la importancia de las prácticas culturales que le dan valor a esa comunidad de personas y a ese lugar en particular.

\section{PRÁCTICAS CULTURALES}

La identidad cultural originaria de los habitantes de Villa Puclaro estaba caracterizada antes de la erradicación por un conjunto de acciones que moldeaban las normas, hábitos y costumbres de la vida de los habitantes, relacionadas esencialmente con las experiencias del ámbito de lo rural, como son el despertar temprano para aprovechar la frescura de la mañana, las siembra y cosecha de los huertos que les permitía autoabastecerse, las relaciones sociales cercanas y heredadas, el trabajo con animales y con viñedos de producción vitivinícolas, los juegos y experiencias cotidianas entre los árboles añosos y el río Elqui, la lechería de la ascienda de Punta azul, la producción de leña de la Polvada y las comidas cocinadas en el calor de los hornos de barro, una tradición que reunía cotidianamente a la familia en torno al hogar.

Otra práctica cultural tradicional e importante para los habitantes erradicados eran las actividades deportivas y recreacionales que se realizaban los fines de semana en la cancha de la Polvada, constituyéndose como el lugar de mayor interacción social junto con la escuela rural que se ubicaba en el poblado.

\section{LOCALIZACIÓN}

En su situación original, la localización de ambos poblados a pesar de estar aislada en relación a su entorno y a las comunidades más cercanas como El Tambo y las ciudades de La Serena hacia el mar y de Vicuña hacia la cordillera, se constituye 
como un valor social que los identifica y que les otorgaba un lugar propio en medio de la belleza del paisaje del Valle de Elqui, que les ofrecía los privilegios de sus cualidades y de la calidad de vida asociada a la cercanía con la naturaleza y que mitigaba, en gran parte, la situación de pobreza que caracterizaba a la población erradicada, y que en el caso de Puclaro estaba condicionada, en una cantidad importante, por personas que vivían en situación de allegados en las viviendas de sus familias nucleares.

Importante es mencionar que sus habitantes no resentían de mayor manera la dificultad de trasladarse hacia servicios básicos como salud o educación. Este fenómeno de acostumbramiento a su realidad rural expresa el arraigo y la pertenencia como factores esenciales en la conformación de la identidad cultural de los individuos. El apego a sus raíces, su tierra y sus viviendas supera con creces los sacrificios de movilidad generados por su localización. De hecho, en las respuestas escritas de las encuestas voluntarias, se expresan claramente sus añoranzas relativas a las condiciones en que vivían en sus pueblos de origen, a pesar de todas las dificultades o necesidades que pudiesen haber tenido. Este fenómeno reafirma la tendencia a la lugarización y su validación de heterogeneidad, como contrapartida a los procesos de la globalización.

174 revista invi №66 / Agosto 2009 / Volumen № 24: 159-190

\section{Transformación del universo simbólico}

En una mirada macro, este concepto clave atraviesa entrelazando a los otros tres. Como ya hemos dicho, se podría asociar a una especie de concepto motor, que a nivel de abstracción de la realidad estaría moviendo el engranaje del proceso de mutación cultural, es decir, influyendo y/o determinando el sentido y la significación de las experiencias cotidianas de los habitantes de Puclaro.

Se relaciona esencialmente con el ámbito de las "motivaciones" como configuraciones simbólicas de los individuos, tanto en los planos conscientes como en los inconcientes de las personas; motivaciones manifestadas generalmente a través de los discursos del ser humano; este sólo hecho fundamenta la aplicación de las Poesías Iconográficas como condensación simbólica de los discursos y como herramienta exploratoria de la dialéctica del sentido ${ }^{12}$.

Estos espacios topológicos emergentes, en el caso de las erradicaciones, llevan implícito la carga significante del mundo de las experiencias en estado de transformación. Es así como podrían validarse herramientas de evaluación a partir del análisis interpretativo de poesías iconográficas, en el sentido que las manifestaciones artísticas tienen

12 Dávila, Andrés, 1995. Pp. 69-83.

ARTíCULO: Proceso de mutación cultural desde experiencias cotidianas en Villa Puclaro / Giancarla Gómez Passalacqua 
inherente las emociones y el mundo interior de los creadores.

\section{Contextualización al caso}

Los habitantes de Villa Puclaro han sufrido transformaciones del universo simbólico, que estarían potenciando el deterioro social y frenando la evolución del proceso de apropiación y de construcción de identidad.

Los cambios en el Universo Simbólico de los individuos comenzaron a forjarse con la inundación de sus poblados, con el hundimiento paulatino de sus terrenos, viñas, huertos, árboles frutales y finalmente de sus viviendas, es decir, la transformación en su construcción de sentido comenzó cuando sepultaron bajo las aguas del Puclaro sus experiencias cotidianas, sus prácticas culturales, sus vínculos sociales y territoriales.

Asimismo, las transformaciones en el universo simbólico de la población erradicada, continuaron su proceso de transición cultural, desde la nueva realidad a la que fueron enfrentados en Villa Puclaro, fundamentalmente dada por los siguientes factores:

- La adaptación a las nuevas condiciones de tamaño y distribución espacial de sus viviendas y de los espacios exteriores disponibles.

- El cambio de vida laboral asociada al trabajo de la tierra.
- La pérdida de espacios comunitarios.

- La transformación y/o pérdida de los espacios de permanencia y recreación propios de la vida rural.

- Localización aislada.

Los factores de transformación anteriores se pueden sintetizar en dos: nuevas experiencias cotidianas y nuevas prácticas culturales.

Estos factores de transformación del universo simbólico, son considerados como la condiciones que determinan la construcción simbólica de los habitantes durante las Etapas de Adaptación y Apropiación, y por ende son asociadas directamente con los efectos socioculturales de la erradicación.

\section{Proceso de mutación cultural como eslabón de enlace}

La transformación simbólica analizada en el punto anterior, sus factores y causas, determinan por ende "el soporte sociocultural y simbólico" del proceso de mutación cultural, generando las condiciones en que se desarrollan sus tres componentes de identidad, pertenencia e interacción social. Asimismo, en su relación sistémica los tres ejes conceptuales claves son a su vez conformadores esenciales de la mutación cultural, de sus representaciones y prácticas culturales, situándose 


\section{BOSOUEJO CONCEPTUAL 4: RELACIÓN SISTÉMICA DEL PROCESO DE MUTACIÓN CULTURAL, MARCADA POR LOS EFECTOS SOCIOCULTURALES DE LA ERRADICACIÓN.}

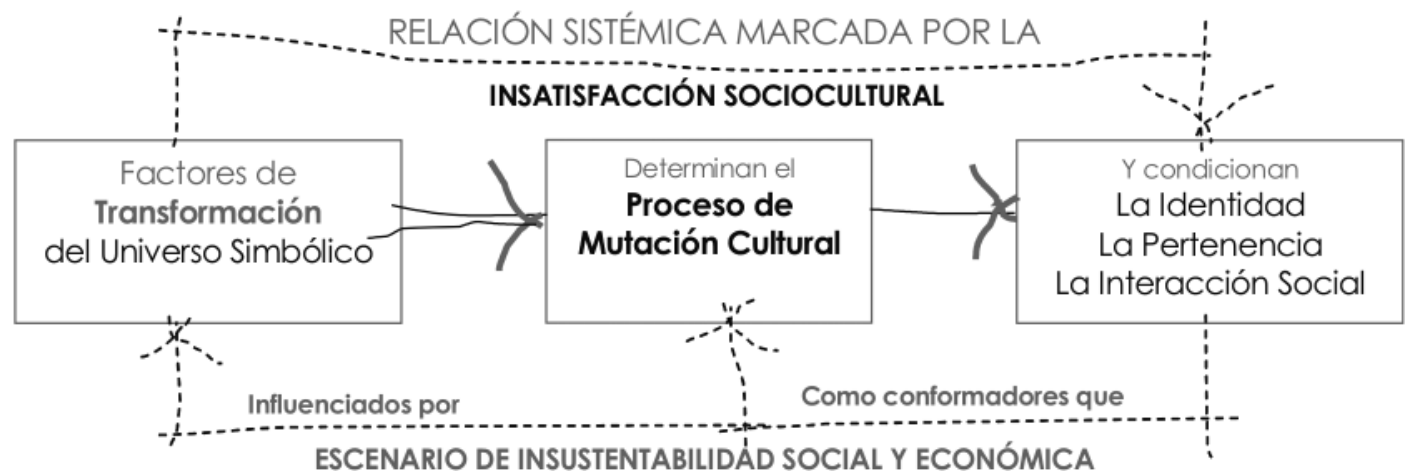

Fuente: Autora

como ejes fundamentales del análisis de todo proceso de erradicación.

Los procesos de mutación cultural, producto de erradicaciones masivas, son generados por la fusión de las experiencias cotidianas y prácticas culturales arraigadas en los habitantes, en conjunción con las nuevas experiencias dadas por la localización y las condiciones de las viviendas y del diseño urbano del conjunto.

Surge así, la necesidad de precisar algunas visiones en torno al tema de la cultura.

La cultura, como término en sí mismo, está sujeta a una diversidad de definiciones que la complejizan desde el punto de vista de su concepción y alcance ${ }^{13}$, es decir, la cultura implica una conjunción multidimensional de factores sociales y territoriales naturales y construidos que interactúan para la conformación de pautas de comportamiento, involucrando aspectos subjetivos y objetivos, es decir, lo intangible como la dimensión simbólica de la conducta humana y también lo tangible y observable, que coexisten en una relación constante y permanente de construcción colectiva y de comunicación.

Desde esta perspectiva, el proceso de mutación cultural en Villa Puclaro se estaría conformando

13 Pfenniger, Mariana. 2004 
desde el escenario complejo de sus insatisfacciones socioculturales, como expresión de las necesidades no resueltas, que estarían provocando en alguna medida el deterioro social y urbano del poblado. Se declaran como causas de la insatisfacción, los conflictos sociales, las nuevas problemáticas sociales, la carencia de interacción social, el desarraigo y la pérdida de espacios físicos y sociales, el estancamiento de la ubicación social, la carencia de oportunidades y la pérdida de identidad.

Estos factores de insatisfacción sociocultural están determinando el proceso de mutación cultural del poblado erradicado y son claramente los signos visibles de problemáticas profundas que se basan en el abandono social, político y económico en que se encuentran actualmente los habitantes de Puclaro y que se traduce en una inevitable condena de insustentabilidad.

La problemática esencial del desarrollo urbano sostenible se podría ejemplificar en la erradicación total de dos poblados agrícolas y en la construcción del Embalse Puclaro, a favor de los procesos avasalladores del crecimiento económico y la globalización, que provocan la transferencia de externalidades. En este caso, desde los beneficios de asegurar el agua de regadío para los grandes productores del Valle de Elqui y potenciar sus exportaciones; hacia la transformación radical del paisaje y de las vidas de un centenar de familias, con los costos ecológicos y sociales involucrados.
Se podría decir, desde el punto de vista del desarrollo sustentable, que se generaron externalidades negativas en lo local, por externalidades positivas en lo global.

Dichos efectos locales-globales del desarrollo sustentable asociados al deterioro social y urbano del hábitat residencial, generalmente son absorbidos por sectores de pobreza urbana, en este caso, por la pobreza rural de pequeños agricultores que subsistían como temporeros de la uva en grandes asciendas como Punta Azul. El resultado de la erradicación generó la localización del nuevo poblado como una clara expresión de los poderes involucrados y de su decisión bajo la lógica del mercado, con un diseño urbano deficiente por la concepción de "conjunto habitacional sin equipamiento complementario" y por su emplazamiento en una zona carente de infraestructura y servicios, generando un germen de consecuencias económicas y sociales; potenciando la posible alienación y delincuencia, y consecuentemente el rechazo de posibles actividades económicas, agudizando la segregación espacial, la exclusión social y la inequidad en la calidad de vida de las personas.

Se vuelve relevante, bajo la perspectiva sostenible, vincular políticas participativas locales con las diferentes escalas en que se interrelaciona la Villa Puclaro como un sistema integrado, bajo la visión de una "racionalidad global" que garantice 
un futuro desarrollo económico, social y cultural en lo local.

\section{Construcción de nueva identidad cultural}

Como ya hemos visto en los puntos anteriores, los fenómenos contemporáneos de la identidad que tradicionalmente eran de exclusiva relación con el territorio, han cambiado su concepción por los procesos de la globalización y de las tecnologías de la información, provocando que la conformación de identidades territoriales no esté vinculada necesariamente al espacio en su connotación de realidad física, asociada a la distancia y proximidad, sino más bien, ha transformado la vida de las personas hacia experiencias cada vez más desligadas del lugar, transitando cotidianamente en una realidad ambivalente entre lo concreto y lo virtual.

Desde este escenario difuso, que complejiza aún más la realidad de los habitantes de Puclaro, se podría analizar, que a pesar del evidente aislamiento físico del poblado, parte de los individuos residentes está conectado al mundo global a través de las comunicaciones y de las tecnologías de la información; asumiendo esta dualidad de escalas y vínculos de conexión entre lo local y lo global.
La nueva identidad territorial se podría conformar a partir de nuevos códigos socioculturales, plasmados en objetivos comunes que motiven la construcción de adhesiones y de interacción social, ya no desde la pertenencia o proximidad, sino más bien, por factores que movilicen a los individuos en proyectos comunes, con sentidos compartidos, que representen sus intereses $y$ necesidades personales, que potencien las identidades locales desde objetivos colectivos surgidos por las experiencias de vida "desde" la interdependencia global y de flujos crecientes, es decir, desde la cercanía de su cotidiano inmersa en relaciones cambiantes y dinámicos de lo local (lugares) con lo global (flujos) ${ }^{14}$

Las nuevas motivaciones de las personas se vinculan a la identidad y al territorio desde sus propios proyectos de vida, compartiendo objetivos generalmente de calidad de vida, seguridad y confort. En el caso de los habitantes de Villa Puclaro, los objetivos o proyectos comunes estarían esencialmente asociados al mejoramiento de las condiciones de sus viviendas, asimismo del espacio público deficiente y a la inexistencia de equipamientos y de servicios en el poblado.

Desde esta perspectiva contemporánea, se podría fundamentar que la nueva identidad en construcción está determinada esencialmente por

14 Barreiro, Fernando. 2002. 
el motor generador que surge desde las nuevas experiencias vividas por los habitantes durante el proceso de erradicación, así como también de aquellas experiencias cotidianas que se han ido adaptando y/o modificando por las nuevas condiciones arquitectónicas, urbanas y sociales en que se está desarrollando la vida en Villa Puclaro, que se constituyen como el soporte desde donde surgen sus "necesidades de vida", en lo individual y en lo colectivo.

Los factores de transformación del universo simbólico analizados anteriormente, nuevamente aparecen como relevantes en la construcción de identidad, puesto que desde allí se soportan las dinámicas de las experiencias cotidianas. Por ende, aparece esta nueva identidad emergente como el componente de "resultado" de la relación sistémica entre simbolismo, identidad, pertenencia e interacción social.

Esto nos sitúa en el mundo social multidimensional en que se está desarrollando el "eslabón de enlace cultural" de los poblados erradicados, que además como condición particular está constituida por habitantes provenientes de dos pueblos diferentes, que han tenido que forzosamente construir una identidad en común; las experiencias sufridas por ambos pueblos en la erradicación son actualmente el vínculo social intangible de mayor relevancia que marca el inicio de su mutua construcción de sentido.
Desde una mirada macro, la construcción de sentido y significación de Puclaro está marcada por dos fenómenos que se asocian a los procesos de globalización, éstos son la exclusión social y la segregación urbana, que sumado a las prácticas laborales temporarias como su principal fuente de ingresos, y a la inexistencia de fuentes laborales al interior del pueblo, asimismo de equipamientos y servicios básicos, generan una gran movilidad cotidiana de la población, que debe trasladarse diariamente a los poblados vecinos y a la ciudad de Vicuña, para acceder a sus lugares de trabajo, de estudios y servicios, además para satisfacer necesidades de abastecimiento, recreación y salud.

Lo anterior determina una condición particular del habitar, marcado por el dinamismo de personas en horas de la mañana por la salida del pueblo, y su posterior llegada por la tarde noche, generando una situación de "pueblo dormitorio" que sobrevive en permanente flujo, con todo el coste de oportunidad que significa para los ámbitos personales y familiares, generador de deterioro social y urbano para sus habitantes.

La construcción de identidad de habitantes erradicados, entrelaza los valores que permanecen en la memoria colectiva de las personas con las nuevas experiencias cotidianas. Es por ello relevante investigar sobre el universo simbólico y su lugarización, para fortalecer a través de acciones los valores de lo local y de la heterogeneidad 
como una manera de acceder a las dinámicas de competitividad que exige el mundo globalizado.

\section{El cómo observar: poesías iconográficas}

Se plantea una metodología de observación basada en un enfoque cualitativo, con el apoyo de observaciones cuantitativas que complementarán y potenciarán la interpretación de información recopilada.

Según lo anterior, se propone la observación de los aspectos simbólicos de las experiencias cotidianas a través de la interpretación de Poesías Iconográficas, es decir, representaciones líricasilustradas, creadas por los propios habitantes erradicados, situándola en dos momentos espacio temporales, antes y después, de la Erradicación, estructuradas conceptualmente en una línea de tiempo, estableciendo cuatro sub momentos: La Poesía Iconográfica del amanecer; del medio día; del atardecer y del anochecer.

La metodología interpretativa pretende profundizar en el significado de las imágenes poéticas, descubriendo el mundo de las motivaciones y el Universo Simbólico a través de la palabra y su semántica.

180 revista invi № 66 / Agosto 2009 / Volumen No 24: 159-190
La aplicación de Poesías Iconográficas como instrumento de evaluación del hábitat residencial y de los procesos de erradicación, se fundamenta por los aspectos subjetivos e intangibles de la cultura como ámbito complejo, y se basa conceptualmente en la comprensión del discurso lírico desde la imagen poética de Gastón Bachelard ${ }^{15}$, y su reflexión de habitar como esencia del concepto de hogar, que trae intrínseco los ecos del pasado y su "sonoridad del ser" a través de la palabra; ligado con la poética de la habitabilidad y de la morada de Martín Heidegger ${ }^{16}$, en su constante de "volver al origen" y dotar de vida las cosas en el trato cotidiano.

Desde las expresiones iconográficas, el poder comunicativo de los imaginarios urbanos de Armando Silva ${ }^{17}$, con sus múltiples sentidos y significados, al igual que la poesía en su valoración simbólica que trasciende la palabra, nos habla del espacio urbano como espacio simbólico de encuentros y desencuentros, espejo de la transformación de la identidad como proceso. Y como objeto de inspiración de las poesías iconográficas -las experiencias cotidianas-, entendidas con la visión polisémica del viaje cotidiano de Humberto Giannini ${ }^{18}$ y su concepción de domicilio como espacio simbólico.

\footnotetext{
15 Bhachelard, Gastón. 1965.

16 Heidegger, Martín. 1997.

17 Silva Armando, 1992.

18 Giannini, Humberto. 1987.
} 


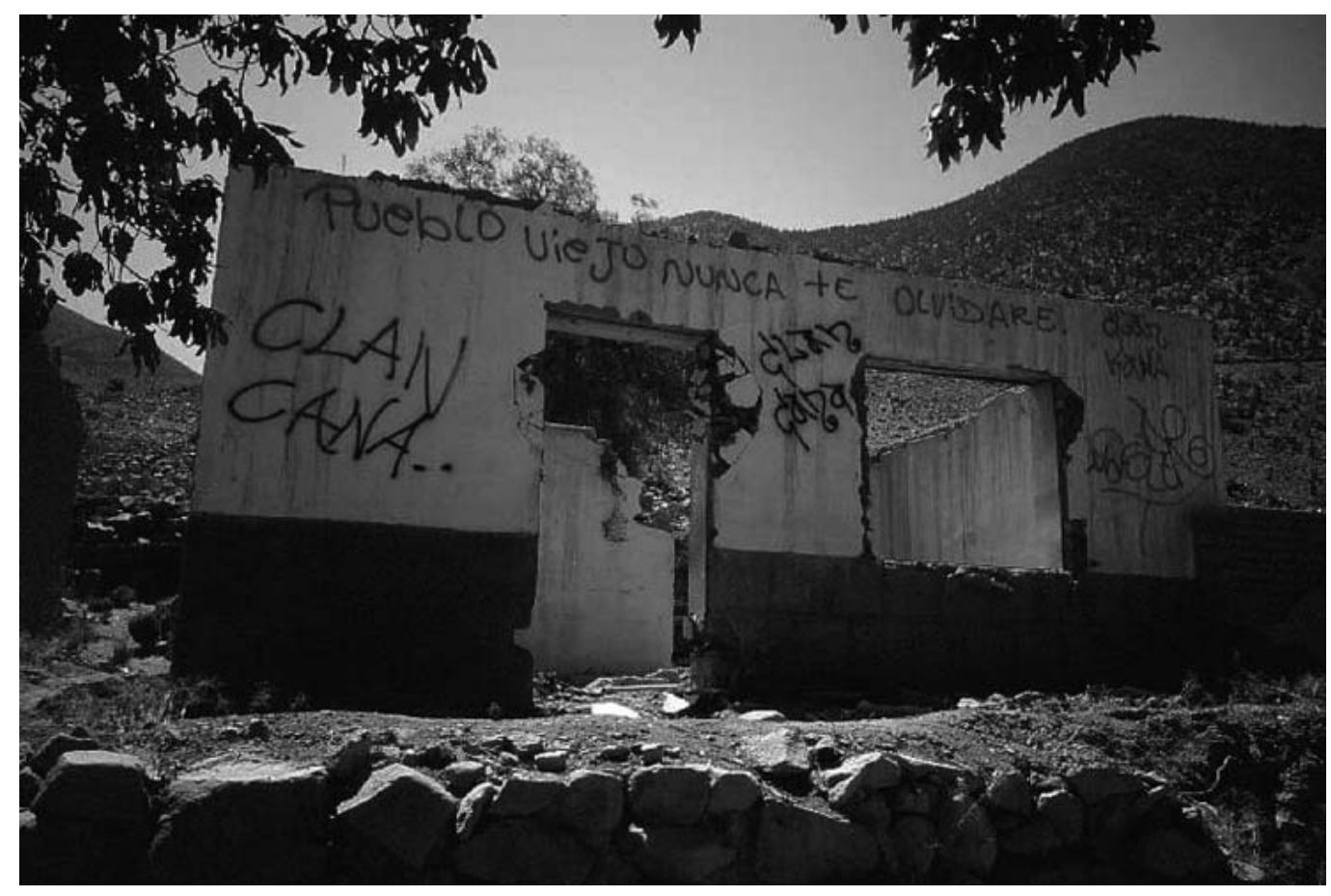

Imágenes Poéticas expresadas en las ruinas de los Pueblos sumergidos por el Embalse Puclaro.

Fuente: En línea. 2009. [fecha de consulta: agosto 2008]. Disponible en: http://www.gualliguaica.cl/antiguo.html 
Para fundamentar la metodología de investigación de Poesías Iconográficas, se establece como primer soporte de análisis el ámbito de las ciencias sociales y las refiguraciones del pensamiento social, que ponen en valor la interpretación como mecanismo generador del descubrimiento del orden en la vida colectiva y sus relaciones sistémicas, que logran comprender dicho orden social, desde la indagación de casos o conjunto de casos, enfatizando en los rasgos particulares que la distinguen, siendo éstos, signos cargados de significados, relativos al modo en que los seres humanos interactúan como seres individuales y colectivos. ${ }^{19}$

\section{Matriz interpretativa de poesías iconográficas}

Lo instituyente de la propuesta es la Matriz Interpretativa de poesías iconográficas, que persigue la detección de problemas bajo una interpretación integral de sus imágenes poéticas, asumiendo la complejidad del hábitat residencial, al cruzar la información en una matriz de doble entrada que estructura horizontalmente la información en tres ejes conceptuales: identidad,

19 Profundizando el tema de la interpretación, "la tendencia hacia una concepción de la vida social como algo que está organizado en términos de símbolos (signos, re-presentaciones...), cuyo significado (sentido, valor, significación) debemos captar si es que queremos comprender esa organización y formular principios...". Geertz, Cliffort. 1980. Pp. 165-179. pertenencia e interacción social; y verticalmente en tres ámbitos: Ámbito de las Motivaciones de Valor Ontológico, Ámbito de las Interpretaciones de Valor Fenomenológico y Ámbito de las Propuestas de Valor Instrumental.

Un primer nivel de Interpretación permite en sentido vertical, registrar las interpretaciones del discurso y de las imágenes, ordenando las experiencias cotidianas y/o necesidades, añoranzas y sueños según Identidad, pertenencia e interacción social.

Un segundo nivel de Interpretación permite en sentido horizontal, interpretar y ordenar por jerarquía, en los tres ejes conceptuales, las prácticas culturales valoradas, mantenidas o modificadas, y las prácticas culturales definitivamente nuevas, correspondientes a las experiencias de Villa Puclaro.

Para establecer las conclusiones de la matriz interpretativa, entiéndase como las propuestas o estrategias socioculturales que pudiesen facilitar el proceso de Adaptación y Apropiación, se asocian tres factores con el objetivo de lograr coherencia y pertinencia al problema de estudio. 
Éstas son: las causas generadoras de deterioro establecidas previamente para cada eje conceptual; la jerarquización de prácticas culturales valoradas; y los tres ejes conceptuales de construcción del proceso de mutación cultural: identidad, pertenencia e interacción social.

Se destaca en la matriz la relación interpretativa en sentido transversal a los tres ejes conceptuales como una manera de cohesionar el análisis de la interpretación de imágenes poéticas e imaginarios simbólicos, con el objetivo de lograr la detección de problemas bajo una visión integral de la realidad, recogiendo la complejidad del hábitat residencial contemporáneo.

\section{El qué observar}

Ya definimos anteriormente el cómo de la metodología planteada -la interpretación-, ahora nos centraremos en comprender el qué de la metodología, es decir, hacia dónde dirigir la observación. Es así, como surge la inquietud de escudriñar en un foco de información que tuviese la fuerza comunicativa (aunque muchas veces invisible) de los fenómenos que están construyendo el proceso de mutación cultural en habitantes erradicados, enfatizando en más allá de lo evidente, con el objetivo de comprender aquello que pudiese permanecer encarnado en la conciencia. Observar la transformación del universo simbólico de habitantes erradicados, desde las experiencias cotidianas, es atravesar transversalmente la reconstrucción de identidad y arraigo como reflejo del motor ontológico que inunda de nuevos significados el proceso de mutación cultural, comprendiendo sus factores y causas, permitiendo definir "el soporte sociocultural y simbólico" que construye, en definitiva, el eslabón de enlace cultural.

El observar las imágenes poéticas de lo cotidiano, es introducirnos en la construcción cultural y simbólica de poblaciones erradicadas, con el objetivo de aproximarnos a identificar unidades de sentido o espacios topológicos propios de una comunidad y un territorio en transición, estableciendo vínculos entre prácticas culturales perdidas y aquellas que han logrado permanecer en el proceso de adaptación y apropiación, en conjunto con la detección de nuevas prácticas simbólicas de los habitantes.

\section{Algunas conclusiones para la tesis}

\section{ESPACIOS TOPOLÓGICOS Y ANTICIPACIÓN DE PROBLEMAS}

El análisis integral y sistémico de las imágenes poéticas como expresión de la diversidad de espacios de mundos que interactúan en un grupo social, pretende aportar a la detección de patrones 
BOSQUEJO CONCEPTUAL 5: TRANSFORMACIÓN DEL UNIVERSO SIMBÓLICO COMO FUNDAMENTO DE LA OBSERVACIÓN DEL TRASFONDO ONTOLÓGICO DE LAS EXPERIENCIAS COTIDIANAS, DESDE UNA METODOLOGÍA INTERPRETATIVA DE POESÍAS ICONOGRÁFICAS.

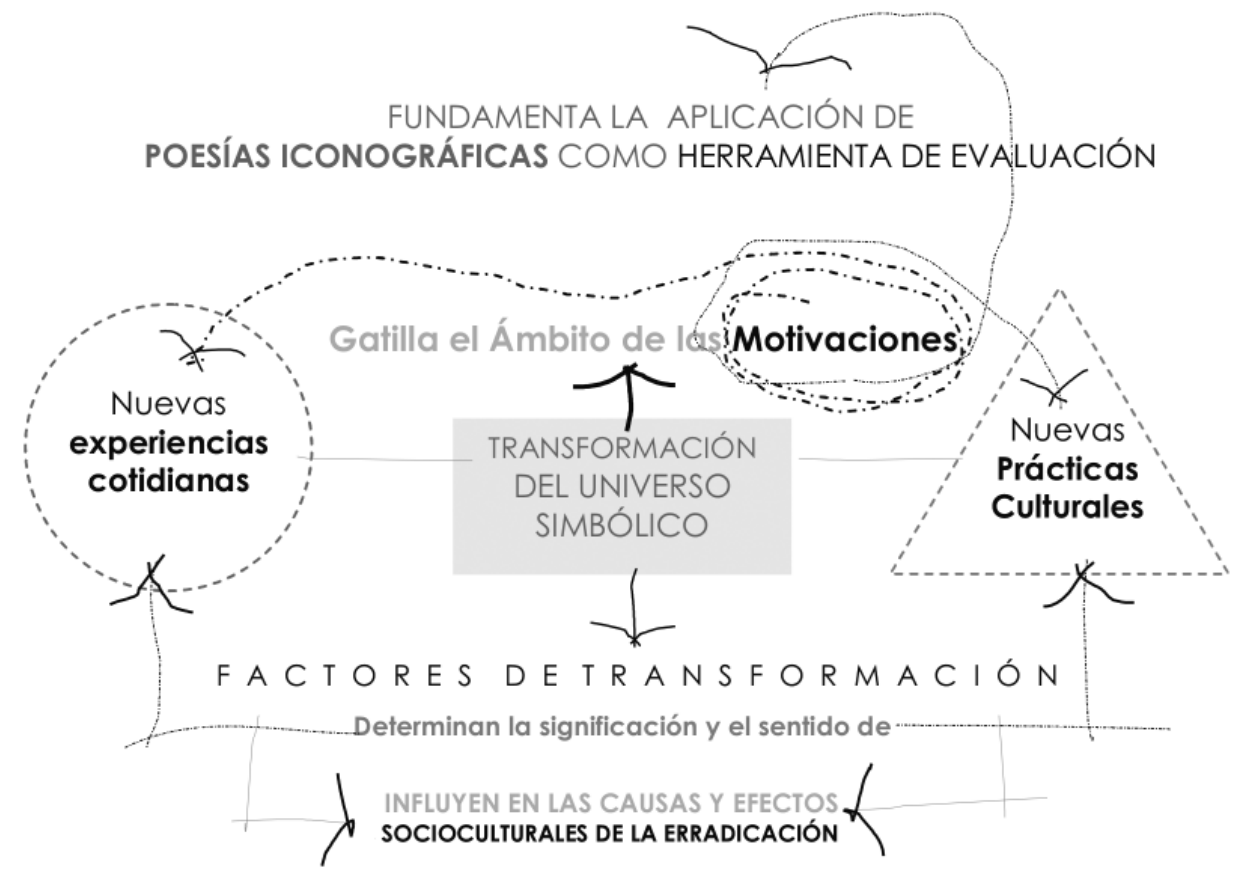

Fuente: Autora. 

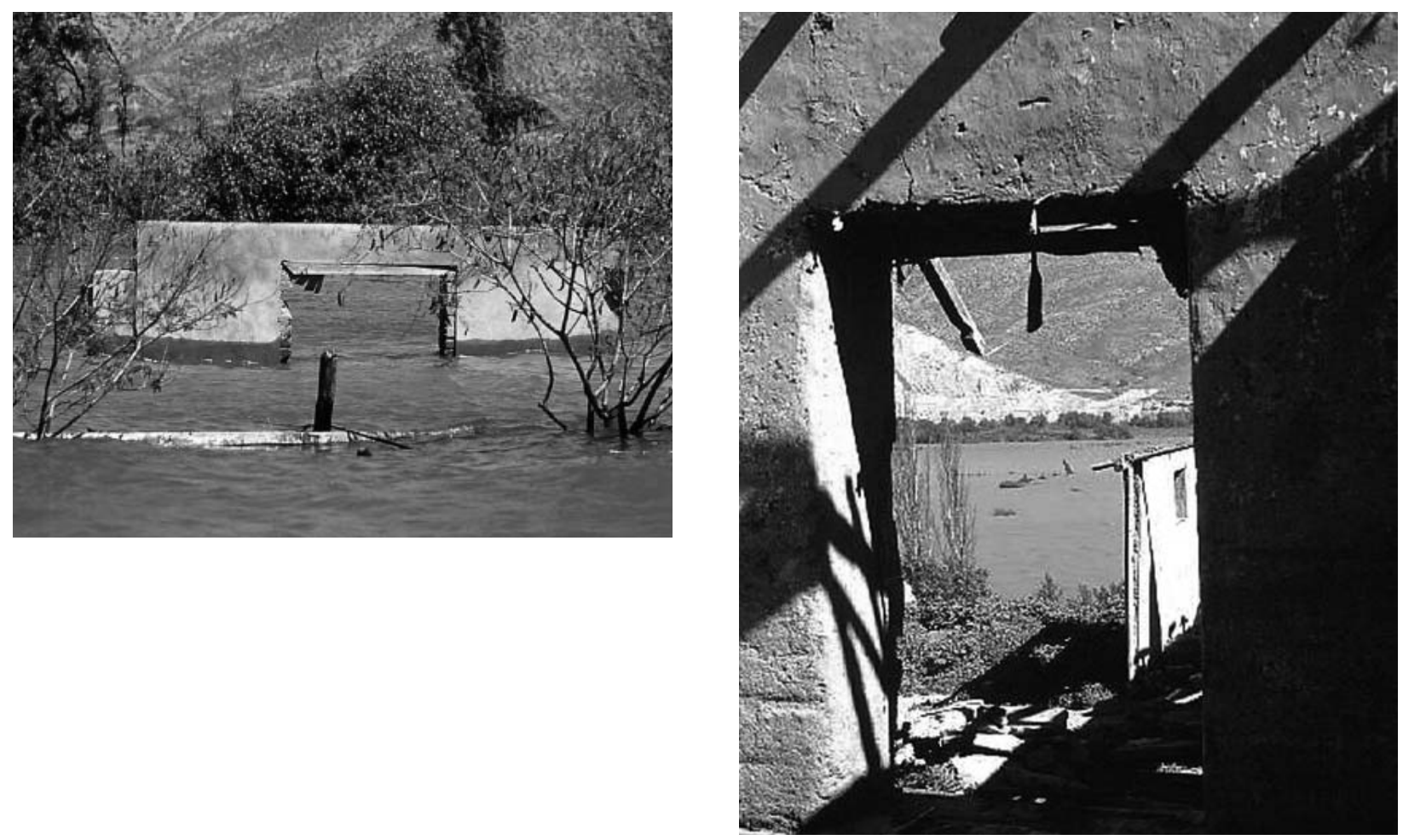

Proceso de transformación del territorio, por la acumulación de las aguas del embalse y el hundimiento de la identidad de tres poblados del Valle de Elqui.

Fuente: En línea. 2009. [fecha de consulta: agosto 2008]. Disponible en: http://www.gualliguaica.cl/antiguo.html 
simbólicos factibles de utilizar en la toma de decisiones y en la anticipación de problemas.

La interpretación del discurso lírico y sus dibujos representativos, motivados desde las experiencias cotidianas del "antes y el después" de la erradicación, deberían ser capaces de generar una sinergia de información que proporcione los suficientes "llamados de atención" en temáticas o situaciones contractuales, que podrían estar siendo focos de conflictos sociales al interior de la población y/o problemáticas externas, relativas a la gestión de actores públicos y privados o, por el contrario, a su inexistencia o necesidad.

Uno de los desafíos de la investigación y la metodología planteada, es verificar por lo tanto su capacidad de anticipar problemas, con el objetivo de aportar a la recuperación de tejido social y urbano del hábitat residencial de familias que obligadamente asumen los costos sociales de las erradicaciones.

\section{RELACIÓN TRANSVERSAL IDENTIDAD- PERTENENCIA-INTERACCIÓN SOCIAL Y SU CRUCE CON LA DETECCIÓN DE PROBLEMAS}

Desde las diferentes perspectivas del hábitat residencial, los procesos de transformación cultural y territorial entrelazan los componentes de identidad, de arraigo y de interacción social, en una especie de trama ontológica del habitar, que se configura de manera difusa, no claramente delimitados uno de otro. Por ende, lo que debe pretender hacer la matriz interpretativa de poesías iconográficas es precisamente categorizar las imágenes poéticas y la imaginería gráfica en dichos tres componentes, pero no bajo una visión "separatista" y ensimismada, sino más bien con la premisa de visualizar sus interrelaciones para comprender, desde la simpleza, la complejidad del hábitat residencial.

Por tanto, la vinculación inherente de un componente con el otro va encadenando sus relaciones como un tejido único, que desde un pensamiento estructuralista -la identidad y la pertenencia- presentan una ligazón indivisible. Sin embargo, la interacción social sugiere ser un componente que podría ser el generador de los dos primeros, o contradictoriamente, la consecuencia de ellos. Esta ambivalencia de relaciones es el fiel reflejo contemporáneo de una realidad compleja. La forma que la metodología de evaluación propuesta se hace cargo de aquello es a través de la interpretación transversal de los tres ejes conceptuales en la Matriz de Poesías Iconográficas, que relaciona horizontalmente la información con el objetivo de definir carencias o detectar problemas implícitos en los discursos poéticos. Asimismo, analizarlos en relación vertical a través de la interpretación de sus fenómenos asociados, luego en sus múltiples significados y posteriormente 
en su potencial de sugerir acciones tendientes a intervenir en los efectos socioculturales de la erradicación, fundamentando así, la interpretación de "imágenes - problemas" y la pretensión holista de sus resultados.

\section{CUESTIONAMIENTOS A INVESTIGAR}

Quedan expuestas algunas interrogantes a investigar, tales como identificar ¿cuáles son las representaciones y prácticas culturales de carácter simbólico en los procesos de mutación cultural y transformación territorial?, en tanto, ¿cuáles serán las nuevas formas o espacios simbólicos en que se está construyendo la identidad, la pertenencia y la interacción social de los habitantes erradicados?

Desde estos cuestionamientos, la expresión poética de Punta Azul simboliza las causas generadoras del deterioro social, nos habla de un Universo Simbólico marcado por la insatisfacción sociocultural, consecuencia de frustraciones típicamente contemporáneas, generadas desde las problemáticas asociadas a la globalización y al manejo inadecuado de sus procesos de implementación, y en definitiva, al incumplimiento de sus promesas, vinculadas a la prosperidad con calidad de vida, a la reducción de la pobreza y a la garantía de la estabilidad del crecimiento económico ${ }^{20}$, convirtiéndose más bien, en una poesía a la inequidad de sus beneficios.

20 Stiglitz, Joseph. 2002.

\section{CONCLUSIONES DE GESTIÓN DE ERRADICACIONES}

Se dejan enunciadas dos temáticas generales que rodean las problemáticas estudiadas en los dos trabajos monográficos, referidas a la dimensión Social, Política y Económica del hábitat residencial. Las dos temáticas se relacionan entre sí y se establecen como conclusiones a nivel macro.

Se declara la necesidad de generar un Plan de Gestión y Desarrollo Integral de Erradicaciones y la creación de una Entidad Especializada, que se haga real cargo de las poblaciones afectadas a través de instrumentos que se integren de manera pertinente a los planes y programas gubernamentales, como herramientas flexibles capaces de contextualizar sus procesos. Asimismo, que proporcione actores sociales responsables, informados y respetuosos con la causa, que apoyen efectivamente a las personas erradicadas en las etapas de información y negociación, relativas al valor de sus propiedades y terrenos, que asesoren en la elección de la nueva localización, que establezcan la mediación en el desarrollo de un diseño urbano y arquitectónico que ponga en valor la identidad y la forma de vida de los grupos sociales afectados, permitiendo potenciar su capital social y sus prácticas culturales, acompañando de manera permanente a los habitantes durante los procesos 


\section{BOSOUEJO CONCEPTUAL 6: CONCLUSIONES GRAFICADAS COMO DIAGRAMA DE COHERENCIA}

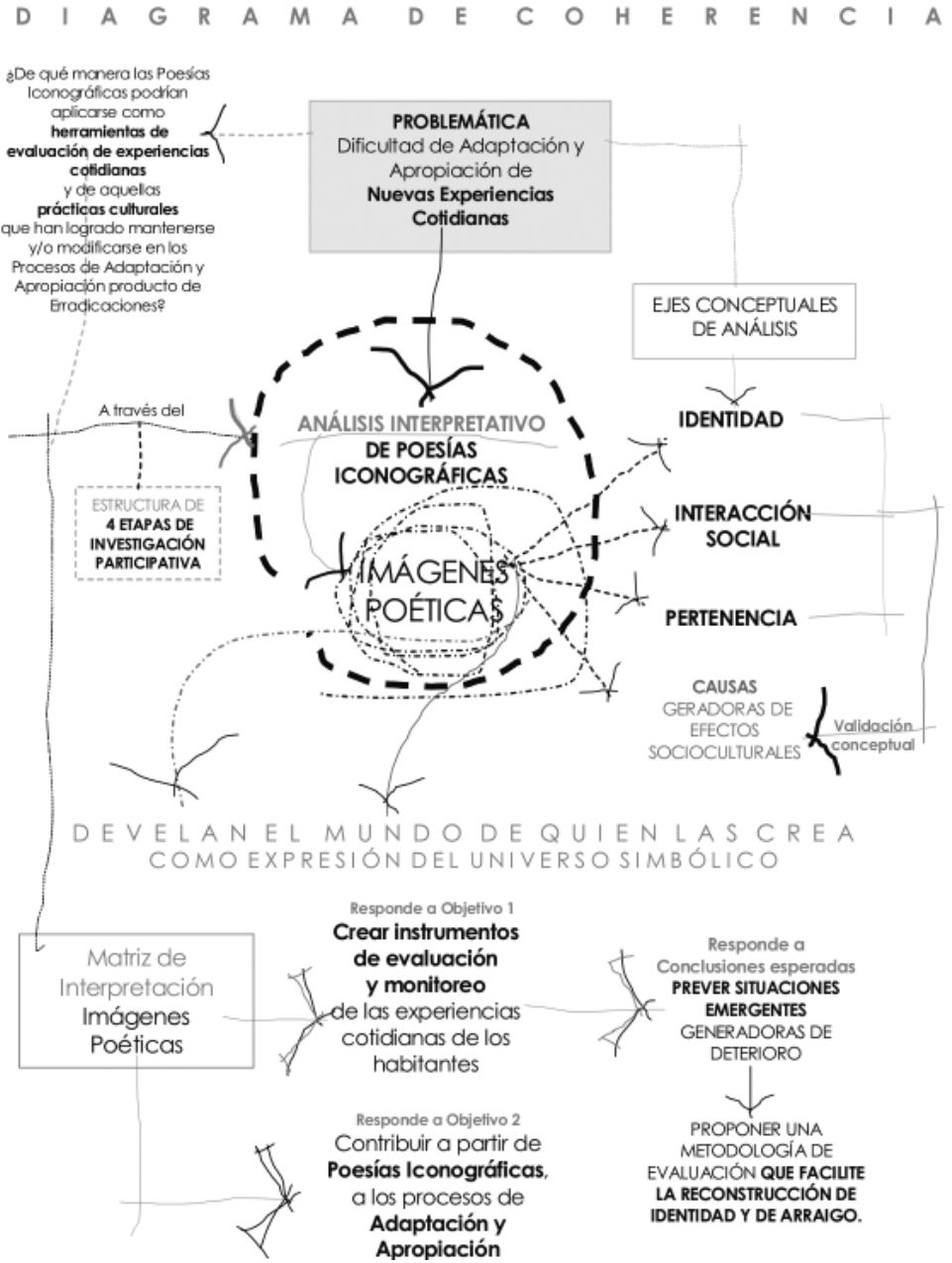

Fuente: Autora 
de adaptación y apropiación a su nueva realidad, con el objetivo de detectar situaciones conflictivas y gestionar acciones remediales pertinentes $y$ oportunas.

\section{DESAFÍOS DE LA AGENDA FUTURA}

Uno de los principales desafíos para la actual investigación de tesis es profundizar en la reconstrucción cultural de un poblado en transformación, desde los aspectos simbólicos de las experiencias cotidianas, aplicando una matriz interpretativa de poesías iconográficas desde una perspectiva ontológica y fenomenológica de sus imágenes poéticas e imaginarios simbólicos, como una manera de comprender desde lo humano, la configuración de los procesos de erradicación, pero sobre todo a partir de una interpretación responsable, despojándose de prejuicios heredados, abriéndose a una interpretación esencialmente centrada en descubrir el universo simbólico, en una lectura transparente y desde "el otro".

Lo relevante de descubrir el universo simbólico desde el hilo conductor de las causas del problema, sus efectos socioculturales y su vinculación con necesidades o carencias implícitas, es vislumbrar herramientas de orientación de posibles estrategias o acciones de recuperación de tejido social y urbano del hábitat residencial, centrando los esfuerzos, fundamentalmente, en humanizar los futuros procesos de erradicación.

ARTíCULO: Proceso de mutación cultural desde experiencias cotidianas en Villa Puclaro / Giancarla Gómez Passalacqua

\section{Bibliografía}

BARREIR0, FERNANDO. "Los nuevos vecinos. Metropolización, exclusión social y segregación urbana, en las ciudades europeas". Barcelona (España), octubre de 2002. En: Comunidad Virtual de Gobernabilidad y Liderazgo (http:// www.gobernabilidad.cl).

BHACHELARD, GASTÓN. "La Poética del Espacio". Fondo de Cultura Económica, México-Buenos Aires. 1965.

CAMAGNI, ROBERTO. "El Principio de Aglomeración (o de la sinergia)". En: Camagni, Roberto. Economía Urbana. Antoni Bosch Editor, Barcelona, 2005. pp. $21-50$.

DÁVILA, ANDRÉS. "Las perspectivas metodológicas cualitativa y cuantitativa en las ciencias: debate teórico e implicancias praxeológicas". En : Delgado, Juan Manuel, ed.; Gutiérrez, Juan, ed. Métodos y técnicas cualitativas de investigación en ciencias sociales. Madrid, Síntesis, 1995. Pp. 69-83.

GARCÍA, CANCLINI. CUCÓ GINER, JOSEPA. "Espacio, Globalización y Cultura”. En Cucó Giner, Josepa, Antropología Urbana. Ariel, Barcelona, 2004. Pp. 45-79.

GEERTZ, CLIFFORT. "Géreros Confusos. La Refiguración del Pensamiento Social". American Acholar, Vol. 49. No2, Primavera de 1980. Páginas 165-179.

GIANNINI, HUMBERTO. "La Reflexión Cotidiana". Editorial Universitaria, Santiago, Chile. 1987.

revista invi № 66 / Agosto 2009 / Volumen № 24: 159-190 189 
HEIDEGGER, MARTIN. "Ser y Tiempo", Editorial Universitaria, Santiago de Chile, 1997.

MARCUS, GEORGE. FISCHER, MICHAEL. "LaAntropología como Crítica Cultural". Capítulo 3, Comunicación de la otra experiencia cultural: la persona, el yo y las emociones. Amorrortu Editores. Mayo 2000.

PFENNIGER, MARIANA. "Indicadores y estadísticas culturales: un breve repaso conceptual".

Artículo cedido por la autora al Portal Iberoamericano de Gestión Cultural para su publicación en el Boletín GC: Gestión Cultural N ${ }^{\circ}$ 7: Indicadores y Estadísticas Culturales, abril de 2004. ISSN: 1697-073X.

SILVA, ARMAND0, "Imaginarios Urbanos", Tercer Mundo Editores. Colombia, 1992.

STIGLITZ, JOSEPH. "La promesa de las instituciones globales" en El Malestar en la Globalización. Santillana Ediciones Generales, S.L. Madrid, 2002.

TIRONI, MANUEL. "Nueva Pobreza Urbana: Conceptos y Definiciones". En Tironi, Manuel. 2003.Nueva Pobreza Urbana: vivienda y capital social en Santiago de Chile. PREDES. Santiago, 1985-2001. Pp. 27-38.

WONNACOTT, PAUL Y WONNACOTT, RONALD. Capítulo 1 "Problemas y Objetivos Económicos". En: Economía. Tercera Edición, Editorial McGrawHill, pp. $3-27$. 